\title{
Appendix 1: Some of my songs. A portrayal of how music can accompany difficult text. (With YouTube links where possible)
}

\section{"Broken" - my first form of disclosure to my music lecturer.}

Oh who is this person?

I barely recognise myself, Where is the fighter I was once proud of?

Who is this wretch in the mirror before me?

With eyes, without any life in, A smile without the joy, And a touch without the love, And a heart without a soul

(Chorus) The darkness is closing in on me, You know how to crush me, I'm too weak, l'm fighting; l'm trying, not enough, I can't fight you; l'm not strong enough, Oh save me from pain, you're drowning me, Is it too much to ask to just be free? Oh fear in my heart, you're killing me, I can't fight you anymore, I'm broken.

Why did I trust you?

Why did I let myself believe That as a child I would be safe with you? That you would protect me from the pain?

Instead, you hurt and scare me, Laugh at all my tears, 
And then you tease me or scream at me, So I'm your slave of fear and sadness.

(Chorus)

What would you do, if you knew right now, It's a battle for me, a battle for me to live? What would you say if you soon found out,

That you won the battle, there is nothing left of me? Soon, you will learn that it's me you killed, And so I pray one day, you will find a heart and love...

(Chorus)

I'm broken, I'm broken, I'm broken

(Chorus with backing vocals repeating "broken") (Chorus backing following passage) Help me, you're drowning me,

Let me be free, oh, l'm broken, I'm broken.

Save me, stop drowning me, Oh God help me, oh, I'm broken, I'm broken.

I'm broken. 


\section{"The River"}

Stand by this river, let this black water drown me I don't want anyone to catch me, let my sorrow drown please...

Who knows I'm standing here? Should they even give a damn, Perhaps now they can be free, from my burden they carry.

(Chorus) What have I done? What have I become?

I can't live in this much pain, and I don't dare to try again

Friends please forgive me, as I fall to my knees

I can't live in this much pain, and I don't dare to try again...

I'm not worth this fight anymore, and I have no energy

I'm sorry for those who know me, I wish you could all forget me

I'm not being selfish or wrong, surely this is better for all?

How can I live in this pain, how can I steal your lives again?

(Chorus)

What have I done? What have I become?

I can't live in this much pain, and I don't dare to try again

Friends please forgive me, as I fall to my knees

And I feel such sweet relief, no more pain to cripple me

What have I done? What have I become?

I can't live in this much pain, and I don't dare to try again

Friends please forgive me, as I fall to my knees

And I feel such sweet relief, no more pain to cripple me

Stand by this river, let this black water drown me

I don't want anyone to catch me, let my sorrow drown please... 


\section{"Songs from the Ashes"}

Birds, please sing for me,

Let me hear the songs of the silence that you captured

I can hear now,

Birds, let out your secrets

Sing me the songs, of sweet numbers...

(Chorus) From the ash, oh the ash, oh the ash...let their souls be free!

From the footprints in the ash, oh the ash, oh the ash, will you sing their songs?

Songs from footprints in the ash.

When the sun rises,

Let your secrets sing out, let their souls be free

You were a silent witness for so long,

Silent beauty holding them for me...

(Chorus)

Birds, please sing for us,

The voices of the silent, the beauty of the lost,

Birds, please haunt me your songs, from the footprints,

Grey dust from the children, lost souls for you to keep...

(Chorus)

Birds, please sing for me... 


\section{“Ghosts in Mirrors"}

(https://www.youtube.com/watch?v=IK4H0nypIEI)

Looking through this mirror-land; my reflection is not who I am, Where's the girl with her deep, wide eyes?

Where's the child brought up with all the lies?

(Chorus) And l'm walking through this mirror-land

Wondering how to reach the other side,

And I watch you through the mirror, and,

My reflection is not by your side.

(My reflection is not who I am.) - sometimes used.

And you all think that I am right here,

You see me laugh or cry, or maybe touch your arm.

I'm as real as the kiss in the autumn air...

I'm real, but l'm also not quite there...

(Chorus)

Ghosts are calling, can you hear them? X2

Ghosts are calling, can you hear them call?

I am falling, ghosts in mirrors...I am touching, ghosts in mirrors...

I am trapped here, can you hear them call?

(Chorus)

Ghosts are calling, can you hear them? X2

Ghosts are calling, can you hear them call?

Ghosts are calling, can you hear them? X2

Ghosts are calling, I can hear them call. 


\section{"Freedom"}

(https://www.youtube.com/watch?v=kvzqWJ7zrq8)

Hope is a wonderful thing,

If you hold it close to your heart, you'll learn how to sing,

Like the birds in the morning sun, you will be

It's a dawning of beauty, it will set you free

(Chorus) Freedom, like the eagle,

I can spread my wings and fly,

Freedom, I can sing now,

Of my journey to the sky

Freedom, like the eagle,

I can spread my wings and fly,

Freedom, I can sing now,

Of my journey to the sky

Like the phoenix, I burnt through the flames,

And found my way, to freedom.

Strength, you have within.

It lives inside of your heart, so hope can begin It

lives inside your eyes, so you can see What's

right and what is wrong, to set you free

(Chorus)

You can fly, you can fly, you can fly, you can fly away (x2)

Fly with me, fly with me, let's see what it's like to be free

Fly with me, fly with me, fly with me, let's see what it's like to be free

(Chorus $\times 3)$ 


\section{“Don't Look Down”}

At the top of this mountain I stand, If I fall now where would I land?

Would you catch me oh mist circling me?

Would you hold me down safe to my feet?

(Chorus) Don't look down, l've climbed so far From the ashes I've risen, in the light I stand now, I'll spread wide my arms, and close my eyes Breathe deeply the sunlight, I can cry now...

Just don't look down, just don't look down.

Pink sky kisses the clouds,

Beams of sunshine cascade all around,

With my head back I sing to the sky,

Songs of freedom, but also songs of why...

(Chorus)

World, hear my song of freedom,

World, hear me sing from this mountain.

(Chorus)

I won't look down, l've climbed so far

From the ashes l've risen, in the light I stand now, l'll spread wide my arms, and close my eyes Breathe deeply the sunlight, I can cry now... Just don't look down, just don't look down.

Don't look down, you've climbed so far From the ashes you've risen, in the light you stand now, Spread wide your arms, and close your eyes Breathe deeply the sunlight, you can cry now... Just don't look down, just don't look down. 


\section{"Is That Still Me?"}

Daddy, can you hear me? Do you even remember my face?

Mummy, where was your shelter? I needed your loving embrace

Twenty-one years and at last I am free, I look in a mirror; is that sill me?

(Chorus) I have survived, though I don't pretend that means it's all ok I remember the child with the tears left unshed, And the screams that weren't heard, silently crushed in bed

I am a strong adult now, with courage to breathe when it hurts,

With love that through pain, has flourished...yet the nightmares, they never fade.

Where was the world for all those years? It's hard not to feel betrayed.

But I'm loved now with friends who hold me - I'm not that frightened child anymore.

Twenty-one years and at last I am free, I look in a mirror; is that sill me?

(Chorus)

I have survived, and l'm yearning for life and the years that lie ahead,

I remember the child with the tears left unshed,

But now I am free, with strength within me, instead...

Twenty-one years and at last I am free, I look in a mirror; that is still me. 